\title{
Application of "Puerperal Healthy" of Optimization of Postpartum Mother Knowledges that Given Effleurage Relaxation Massage
}

\author{
Herlina $^{1 *}$ \\ ${ }^{1}$ Poltekkes Kemenkes Semarang, Master of \\ Applied Science in Midwifery,
}

Tirto Agung Rd., Semarang Jawa Tengah 50268, Indonesia

Rr Sri Endang Pujiastuti ${ }^{3}$

${ }^{3}$ Poltekkes Kemenkes Semarang,

Master of Applied Science in Midwifery,

Tirto Agung Rd., Semarang Jawa Tengah 50268, Indonesia

\begin{abstract}
The postpartum period is a critical period for both mother and baby. Every mother must have understanding, ability and access to health services. The application of education uses the application of "Puerperal Healthy" and Effleurage Relaxation Massage as a support system in an effort to improve the quality of maternal and child health services. Experimental research with a pre and posttest with control group design approach. Probability sampling techniques with cluster random sampling and simple random sampling numbered 62 postpartum mothers. Data analysis used paired t-test and mann whitney test. The knowledge of the respondents in the intervention group increased by 7.10 and the control group 4.61, the results of the statistical test were significant with $\mathbf{p}=$ 0,000. The application of the "Puerperal Healthy" application and Effleurage Relaxation Massage at each puerperal visit was effective in increasing knowledge of postpartum mothers.
\end{abstract}

Keywords:- Postpartum, "Puerperal Healthy" Application, Effleurage Relaxation Massage.

\section{INTRODUCTION}

The postpartum period is a transition period in the face of new roles as parents. During the postpartum period physical, psychological and social changes occur which can lead to a risk of health problems. ${ }^{1-3}$

Health problems in the post partum period can lead to complications severe if monitoring during the postpartum period is not carried out to the maximum. Most maternal deaths occur in the postpartum period by $60 \%$ due to obstetric complications. Mother's unpreparedness due to lack of information and understanding related to the process of pregnancy, childbirth and childbirth as well as imbalance of mind, emotions, physical and social environment after labor is one of the causes of the problem. $^{4,5}$

\author{
Diyah Fatmasari ${ }^{2}$ \\ ${ }^{2}$ Poltekkes Kemenkes Semarang, Master of \\ Applied Science in Midwifery, \\ Tirto Agung Rd., Semarang Jawa Tengah 50268, Indonesia
}

\section{Runjati $^{4}$}

${ }^{4}$ Poltekkes Kemenkes Semarang,

Master of Applied Science in Midwifery,

Tirto Agung Rd., Semarang Jawa Tengah 50268, Indonesia

The change in the paradigm of postpartum care is oriented to health and independence as a healthy mother who experiences physiological events so that it takes the ability to self to pass through the postpartum period. The public perception that considers postpartum mothers are sick mothers so that all their activities are limited is one of the obstacles in postpartum care. It is important to learn in the postpartum period to increase self-understanding and ability in postpartum care. .,7 $^{-1}$

The government is trying to improve the Maternal and Child Health $(\mathrm{MCH})$ program through the concepts of promotive, preventive, curative and rehabilitative. The Mother's Love Movement Program (GSI) and the Complication Prevention and Delivery Planning Program (P4K) aim to foster understanding and awareness that pregnancy and birth can pose risks and not only is the responsibility of the mother, but also her husband, parents, family and community. ${ }^{8}$

Class of pregnant women as a means of increasing self-knowledge and abilities in care postpartum. Research by the Health Research and Development Agency (Balitbangkes) in 2015 explained that the quality of implementation of pregnant mothers was not optimal. Postpartum health education given during the antenatal period cannot be applied optimally by the mother when the postpartum period arrives. ${ }^{9,10}$

Data on the implementation of pregnant women classes in 2017 shows that $93.76 \%$ of puskesmas in Indonesia have carried out classes of pregnant women 4 times and achieved the Ministry of Health Strategic Plan target of $84 \%$. Postpartum visits from 34 provinces reported that almost $60 \%$ had achieved the KF3 target of $80 \% .^{11,12}$

Pandori et al's research explained that the coverage of $\mathrm{MCH}$ book ownership had reached the target of $95 \%$, but only $50.5 \%$ of mothers used $\mathrm{MCH}$ books properly so that evaluation and development of programs were needed to improve the quality of $\mathrm{MCH}$ services and optimize counseling and home visits by health workers. ${ }^{13}$ 


\section{METHODOLOGY}

Experimental research design with a pre and posttest with control group design approach. This design uses 2 groups, namely the provision of education using the application "Postpartum Healthy" and Effleurage Relaxation Massage for 12-20 minutes given to the intervention group while the control group is given education use the book Mother and Child Health (MCH) and Effleurage Relaxation Massage for 12-120 minutes at each postpartum re-visit. Probability sampling techniques were carried out with cluster random sampling and simple random sampling totaling 62 postpartum mothers. Data analysis used paired t-test and mann whitney test.

\section{RESULT AND DISCUSSION}

After analyzing the research data, the following results were obtained:

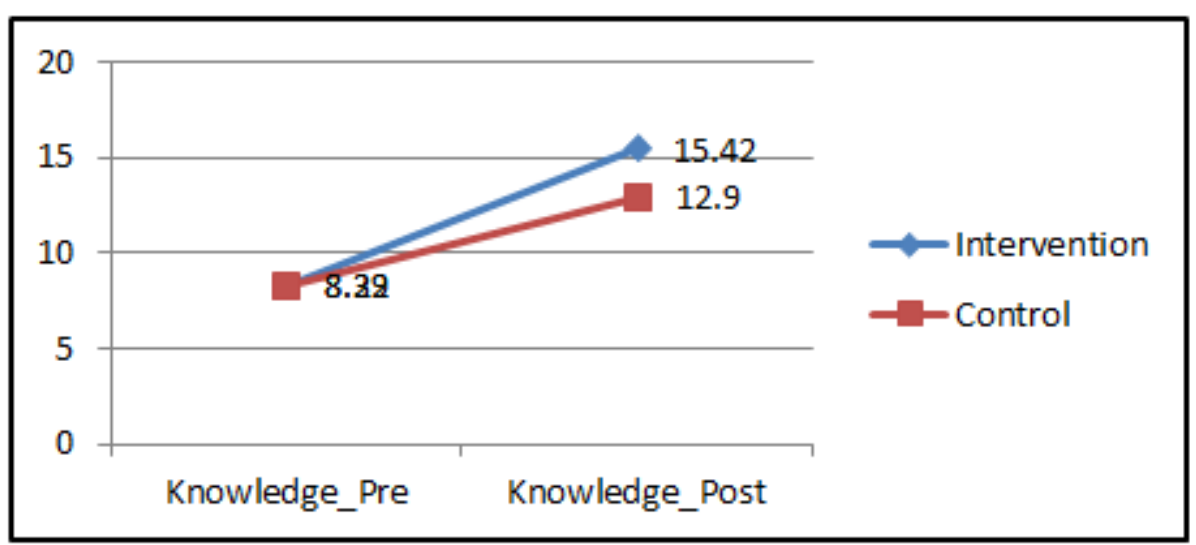

Graph 1:- Changes in Mean Value of Knowledge Before and After Treatment

Data normality test results with Shapiro Wilk $(n<50)$ the mean value of respondents' knowledge before and after treatment in the intervention and control groups were nomal then the paired t-test was continued.

Bivariate analysis results are as follows:

\begin{tabular}{|c|c|c|c|c|}
\hline Group & $\begin{array}{c}\text { Pre } \\
(\text { mean } \pm \text { SD) }\end{array}$ & $\begin{array}{c}\text { Post } \\
(\text { mean } \pm \text { SD) }\end{array}$ & p Value & $\begin{array}{c}\Delta \\
(\mathbf{m e a n} \pm \text { SD) }\end{array}$ \\
\hline Intervention & $8.32 \pm 1.851$ & $15.42 \pm 2.618$ & $0.000^{*}$ & $7.10 \pm 1.814$ \\
\hline Control & $8.29 \pm 1.865$ & $12.90 \pm 2.357$ & $0.000^{*}$ & $4.61 \pm 1.174$ \\
\hline p Value & & & & $0.000^{* *}$ \\
\hline
\end{tabular}

*Paired T-Test

**Mann Whitney Test

Table 1:- Test Effectiveness of Knowledge Value in Intervention Groups and Control Before and After Treatment

The results of the unpaired effectiveness test showed that the $\mathrm{p}$ value in the intervention and control group was $0,000(\mathrm{p}<0.05)$ meaning that education using the "Puerperal Healthy" application and Effleurage Relaxation Massage was more effective in increasing respondents' knowledge compared to education using the $\mathrm{MCH}$ and Effleurage Relaxation books Massage.

Research on providing education using the application "Puerperal Healthy" and Effleurage Relaxation Massage is given once a week each postpartum re-visit for 5 weeks. Every postpartum visit, the researcher made sure the respondent used the "Puerperal Healthy" application and was given an Effleurage Relaxation Massage with a duration of 12-20 minutes for each repeat visit. The difference with the control group lies in the educational media, which uses the $\mathrm{MCH}$ book that the respondent already has.
The mean value of respondents' knowledge before being given treatment in the intervention group was 8.32 and the control group was 8.29 including the lack of knowledge category. After being given treatment in the control group the mean value of respondents' knowledge increased to 12.90 including the category of sufficient knowledge while the group intervention the mean value of respondents' knowledge increased to 15.42 including the good knowledge category.

The "Puerperal Healthy" application was developed with its main content still guided by the book program on Maternal and Child Health (MCH). How to operate the application "Healthy Postpartum" is set and adjusted so that all postpartum mothers can access and use it easily, safely and comfortably. 
The application "Healthy Puerperium" contains information related to postpartum health starting from the understanding of the puerperium, the stages passed during the puerperium, how many times you should check yourself during the puerperium, the needs that must be met during the puerperium, recognize as early as possible signs and hazards the puerperium so it is appropriate to make a referral decision.
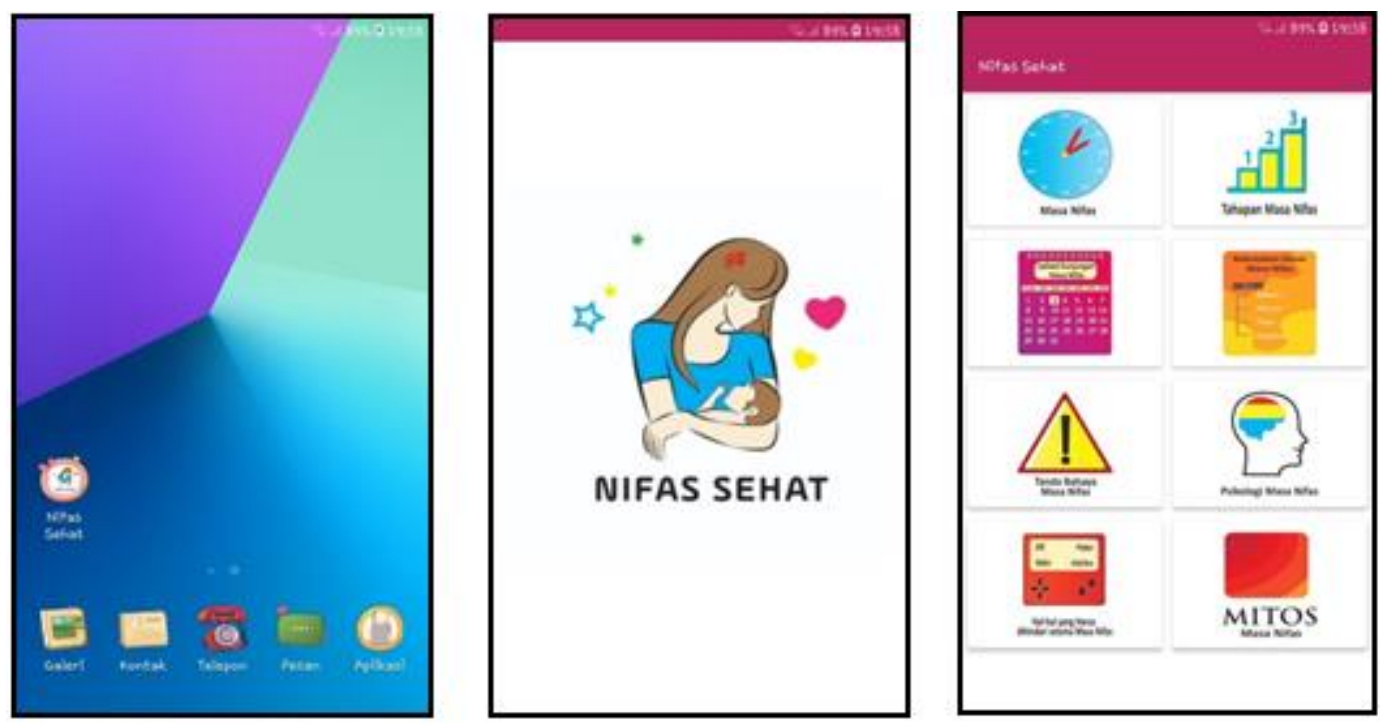

Fig 1:- Display Menu Application "Puerperal Healthy"

The "Puerperal Healthy" application is installed on the cell phone of each respondent in the intervention group via the link https://tinyurl.com/nifas-sehat. Respondents are given information about the steps in using the application and evaluating respondents' understanding. During the time lag before the next postpartum re-visit, the researcher made contact through WhatsApp to ensure the respondent was using the application "puerperal healthy". Most respondents were active in using the application of "Puerperal Healthy" marked by the questions asked by respondents during a postpartum visit related information contained in the application.

Lack of knowledge of respondents before being given an intervention can be due to lack of information obtained about postpartum health due to non-compliance of respondents attending classes of pregnant women and lack of interest in the use of the MCH handbook they have. The research of Ivan Illich and Apriliana et al explains that good knowledge can form beliefs that affect a person's attitude, it is necessary to add knowledge as an initial formation of breastfeeding attitudes. ${ }^{14,15}$

Slomian et al research in accordance with research Feroz, Anam et al explained after giving birth, $90.5 \%$ of women use the internet to find information about their health or baby without regard to age, social and economic status. The most frequently searched for information is breastfeeding. The internet helps $80 \%$ of women in making decisions so that the integration of the internet and new technology can be a useful tool during the deep postpartum improve health services. ${ }^{16,17}$

Research on the android application model "Husband Standby Plus" as an innovation in labor preparation and complications made by Yuanita, Hanna showed the provision of education using a combination of counseling and android applications significantly increased husband and wife scores compared to those who only received counseling. ${ }^{18}$

The results of this study are supported by Sahmad and Majumder's statement, Sharmin et al. that knowledge influences the physical and psychological conditions of the postpartum period. Lack of knowledge and information causes mothers to not understand the importance of postpartum care. There is a gap of maternal knowledge provided by health education between before and after birth, so the implementation of the guidelines on the Maternal and Child Health book needs to be reevaluated. ${ }^{19,20}$

\section{CONCLUSION}

The application of education using the application "Puerperal Healthy" and Effleurage Relaxation Massage at each postpartum visit was proven to significantly influence the increase in knowledge of postpartum mothers.

\section{REFERENCES}

[1]. Ziabakhsh S, Fernandez R, Black B, et al. Voices of Postpartum Women: Exploring Canadian Women's Experiences of Inpatient Postpartum Care. Journal Obstetrics Gynaecology Canada 2018; 40: 14241436.

[2]. Rahayuningsih F.B. Hubungan Aktivitas Ibu Nifas dengan Kualitas Hidup ibu Nifas. Prossiding Konferensi Nasional 2013; 37-40.

[3]. Runjati., Umar S, Ester M. Teori dan Asuhan Kebidanan. 2nd ed. Jakarta: EGC, 2017. 
[4]. Azizatunnisa N, Suhartini. Pengetahuan dan Keterampilan Perawat dalam Pelayanan Keperawatan Holistik di Indonesia. Journal Nursing Studies 2012; 1: $140-148$.

[5]. Sarli D, Sari F. The Effect of Massage Therapy with Effleurage Techniques As a Prevention of Baby Blues Prevention on Mother Postpartum. International Journalof Advancement in Life Sciences Research 2018; 1: 15-21.

[6]. Asmuji., Indriyani D. Model Family Centered Maternity Care sebagai strategi Optimalisasi Competent Mothering. Ners Airlangga 2016; 11: 1728.

[7]. Asmuji., Diyan I. Model Edukasi Postnatal Melalui Pendekatan Family Centered Maternity Care (FCMC). Jurnal Keperawatan 2014; 5: 128-141.

[8]. Diflayzer., Syahredi S.A, Nofita E. Gambaran Faktor Risiko Kegawatdaruratan Obstetri pada Ibu Bersalin yang Masuk di Bagian Obstetri dan Ginekologi RSUD Dr. Rasidin. Jurnal Kesehatan Andalas 2017; 6: 634-640.

[9]. Fuada N, Setyawati B. Pelaksanaan Kelas Ibu Hamil Di Indonesia. Jurnal Kesehatan Reproduksi 2017; 6: 67-75.

[10]. Suplee P.D, Kleppel L, Santa-Donato A, et al. Improving Postpartum Education About Warning Signs Of Maternal Morbidity and Mortality. Nurse Womens Health 2016; 20: 552-567.

[11]. Achadi E.L. Kematian Maternal dan Neonatal di Indonesia. Rakerkesnas 2019; 1-47.

[12]. Kementerian Kesehatan RI. Profil Kesehatan Indonesia 2017. Epub ahead of print 2018. DOI: $10.1002 / q j$.

[13]. Pandori J, Kartasurya M.I, Winarni S. Penggunaan Buku KIA Sebagai Media Edukasi pada Ibu Hamil (Studi di Wilayah Kerja Puskesmas Tlogosari Kulon, Tahun 2018). Jurnal Kesehatan Masyarakat 2018; 6: 63-73.

[14]. Apriliana A, Kuswanto K, Runjati R. Pengaruh Pendidikan Kesehatan Dengan Metode Ceramah Terhadap Pengetahuan Dan Sikap Pemberian Asi Eksklusif Pada Ibu Hamil Primigravida Di Puskesmas Kapuan Tahun 2016. Jurnal Kebidanan 2017; 6: 26.

[15]. Muftianingrum Y, Pudjiastuti S.E, Sawab S. Efektivitas Edukasi Konsep Diri Untuk Meningkatkan Pengetahuan Perkembangan Remaja. Jendela Nursing Journal 2019; 3: 11.

[16]. Slomian J, Bruyere O, Reginster J.Y, et al. The Internet as a source of Information used by Women after Childbirth to meet their need for Information: A web-based survey. Midwifery 2017; 48: 46-52.

[17]. Feroz A, Perveen S, Aftab W. Role of mHealth Applications for Improving Antenatal and Postnatal care in low and middle income Countries: A systematic review. BMC Health Serv Res 2017; 17: $1-11$.

[18]. Santoso H.Y, Supriyana S, Bahiyatun B, et al. Android Application Model of 'Suami Siaga Plus' as an Innovation in Birth Preparedness and Complication Readiness (BP/CR) Intervention. Journal of Family Reproductive Health 2017; 11: 30-36.
[19]. Sahmad. Hubungan Pengetahuan dengan Tingkat Kemandirian Ibu dalam Merawat Diri selama Periode Nifas. Preventive Journal 2018; 2: 70-74.

[20]. Majumder S, Najnin Z, Ahmed S, et al. Knowledge and Attitude of Essential Newborn Care among Postnatal Mothers in Bangladesh. Journal Health Research 2018; 32: 440-448. 